\title{
Fishermen and Inequality: Study About Profit Sharing System in Fisherman Society
}

\author{
Syahrizal ${ }^{1}$ \\ syrizal81@gmail.com \\ Faculty of Social and Political Science, Universitas Andalas, Padang, Indonesia
}

\begin{abstract}
This study based on research about fishers and inequality in relating with profit sharing system between ship crew or worker fishers and bagan ship owner or employer fishers. Profit sharing system was often said to be an unfair system that exploits the fisherman worker or ship crew, but this system has survived until now. Number of bagan ship in Kelurahan Pasia Nan Tigo Padang is around 69 with about 17 until 20 worker fishers for every ship. Each of the bagan ships is still no shortage of fishermen who are willing to work. It raises the question of whether the fishermen feel exploited and the shipowner feels exploiting the fishermen working on them. Research problems are formulated in the following points. First, how the ship owner's views and attitudes toward the rules and practices of the profit-sharing system, which has so far been considered too. Second, how the views and attitudes of the fisherman workers on the profit-sharing system implemented that has been considered to be detrimental to them. Third, why the profitsharing system in the fishermen community remains. This research used a qualitative method by doing observation and depth interview. The profit-sharing system practiced so far is one of the factors causing the inequality, many of the workers complain about this system they feel exploited by their employer, but they can not "violate" or "protest" the system adopted by their employer. These workers argue better still to follow the rules that the owners have set instead of losing their livelihood as a worker. If they feel uncomfortable or incompatible with the employer, they can decide to stop being a crew. If they stop being workers on board, their employer easily gets a replacement. It is because there are still many people who hope to become a worker because they need a job.
\end{abstract}

Keywords: Inequity, Profit Sharing, Fishermen Community .

\section{Introduction}

The fishing community is a community that has a special character that is characterized by their environment in the coastal areas and most of them live in poverty. Their percentage of poverty compared to other community groups such as farmers is much higher.

Among the poor are fishermen who work as crew on ships "bagan". The income of these fishing vessels is related to the profit sharing system which determines the results of the sale of fish after deducting capital to go to the sea divided between the shipowner and the crew.

The purpose of this study is to explain the rules or ideal patterns of the applicable profit sharing system and how these rules can be agreed between fishers. Furthermore, explaining the rules for the profit sharing system are carried out or practiced daily. Then explain the views and attitudes of the owner's fishermen on the rules and practices of the profit-sharing system, which up to now has been considered to exploit labor fishers. Next, it will explain the views and 
attitudes of laborers to the system of profit sharing that has been carried out which has been considered detrimental to them. As well as explaining why the profit sharing system in these fishing communities has survived until now.

\section{Research methods}

The research uses ethnographic research techniques, ethnographic research is considered as a form of research that focuses on social meaning through observation of socio-cultural phenomena. Data collection techniques are through observation, structured interviews and indepth interviews, and observations. The research location is Pasia Nan Tigo Subdistrict, Koto Tangah District, Padang City, West Sumatra, where most of the residents of this Sub-district work as fishermen.

\section{System for Sharing Results and Inequality}

The fishing community in "Pasie Nan Tigo", especially for fishermen "bagan boats" applies a form of profit sharing pattern applied by fishermen owners and laborers working on "chart boats". The revenue sharing system is still valid. This profit sharing between boat owners and labor fishers is carried out once a month when the full moon phase begins, because in that phase fishers do not go to sea, and stop for about five to six days. One month to go fishing or by fishing communities in Padang called one "kalam" can take several days in the sea and several times go back to the mainland to sell their catches during the sea. From this total number of times to go to sea the calculation will be carried out by the management or owner of the "chart ship". Before entering into the profit sharing system that is concentrated by the Fishermen in the "chart boat".

The principle of the profit sharing system in the fishing community in Pasia Nan Tigo is the net yield of fish obtained by the ship for one month or approximately 20 to 25 working days divided into two namely $50 \%$ for the crew and $50 \%$ for the shipowner. The net proceeds are obtained from the difference between the sale of fish and the capital issued by the shipowner for costs and expenses during fishing. The capital is in the form of ship fuel, food ingredients, and pocket money for boat crews which are useful for buyers of cigarettes or other snacks.

However, in practice, there are more out-of-capital expenditures, namely those called commissions. The commission is money obtained by the shipowner for his services to sell fish to fish traders. The commission is usually $10 \%$ of the proceeds of the sale of dried fish cut by the shipowner from the sale. In addition to part of the "chart ship" there is also a discount for the cost of damage to the ship a number of the same as the sales commission that is $10 \%$ of the sale of fish. Furthermore, while not going to the sea for five to six days when the sky is clear, the crew is also required to work on caring for the ship, such as painting or repairing damaged parts of the ship.

The shipowner regulates the profit sharing system on ships "chart boats" in the Pasie Nan Tigo region. In practice, there is a difference between shipowners on the deduction for commission fees and damage to ships. There is a difference in the system of issuing fish sales commissions, where several "chart boats" directly issue commissions after obtaining the total amount of income but there are also those who issue commissions when after spending sea expenses. 
These expenses cut much income earned by "chart boat" in the sea for a month. Moreover, the pieces are not small, which ranges from $20-30 \%$ of the total income. However, if seen from the fish catches from the ship and the results of sales when getting very many and abundant fish, this is not considered significant.

According to the shipowner, the profit sharing system was implemented because the shipowner bore all capital. The "boat chart" is very expensive, between Rp. 500 million and Rp. 800 million. Furthermore, the costs incurred for capital to the sea for each departing ship amounted to tens of millions of rupiah. Meanwhile, according to the owner of the ship, the crew did not issue anything to go to their seafront with enough T-shirts and shorts to work on the boat chart.

On the contrary, for the profit sharing system, crew members exploit them. They consider the profit sharing system to be very unfair because the ones who get the most from their hard work at sea are ship owners. The owner of the ship only has the capital of a ship after which he does not spend money because the ship is run with fish products obtained by the crew.

The income of "bagan", as well as the income of fishermen, are generally not fixed, sometimes many, sometimes medium, sometimes a little, or even none at all. If income is a lot, one "boat chart" can get more than one hundred million in one month. The fish acquisition is influenced by many things such as season, weather, and location. The season is related to the little or the number of fish related to a certain time, the weather determines how bad the weather is, for example, high storms and waves make the "boat chart" unable to go to the sea, and the location is difficult to determine where there are many or few fish. So it can be said that the income from the ship was very fluctuating.

When a ship's income many shipowners will get a large income. The profit sharing system determines that the shipowner gets more than half of the net proceeds of the vessel acquisition. While the crew receives the rest obtained by the shipowner. As an example of a profit-sharing system with a reduction in fish sales commissions and ship repairs, for example, income in one month is IDR 100,000,000. First, the capital is reduced to the sea, for example for one month it is Rp. 20,000,000, - so the rest remains Rp. 80,000,000. Furthermore, the fish sales commission is $10 \%$ of the proceeds of the sale, that is Rp. $10,000,000$, - the rest becomes Rp. $70,000,000$. Finally, for the improvement of the ship, the remaining $10 \%$ will be Rp. $60,000,000$. The remaining Rp. $60,000,000$ is then divided into two by the crew so that each gets $R p .30,000,000$.

The share of the owner of the ship is more than half, namely Rp. 30,000,000, plus a commission on fish sales and repairs to the ship to Rp. 50,000,000. While the crew receives Rp. $30,000,000$. The number of crew members on average is 20 people so on average they get a share of $\mathrm{Rp} 1,500,000$ per person.

The effects of these differences, although touching the most important thing, were agreed upon by most fishermen who owned the "chart boat" at Pasie Nan Tigo. It still has a fairly clear impact on his subordinates, namely the fishermen who work for him. The difference that shows the inequality is seen in the economic and educational aspects of children between ship owners and ship's children, who have the most important role in the smooth running of their business.

Clearly and plainly the inequality can be emitted from residential houses between the owners of the "boat chart" and the crew which are very much different. Where can be ascertained the owner of the "chart boat" has a house that is quite magnificent and symbolizes the strength of the upper-middle-class economy whereas most the crew residences or labor fishermen occupy very modest semi-permanent homes and even contract at the homes of indigenous people in Pasie Nan Tigo.

It is one form of inequality that appears on the physical side between the owner of the "chart boat" and the crew. If it is explored more deeply and an analysis of the system of sharing results 
is applied, it can be found that the factors that cause inequality occur. The "boat chart" profit sharing system at the top floor that we know basically that we know is the residual income after the one-time "kalam" expenditure on sea expenses is for the same 50:50 between the owner and the crew.

The weakness of the revenue sharing system also arises from the lack of clarity and ineffectiveness of some shipowners in recording sales reports and reducing the revenue of "ship chart" during fishing at the same time. Many crews are complaining about this. This imbalance was also added by the amount of daily money received by the ship crew. The calculation of the daily money itself according to the crew is unknown. They only "agreed" with the amount of daily money determined by the management and ship owner of the chart.

Although the crew of the ship were aware and aware of the weaknesses of the profit sharing system and sometimes they felt complained about the "induak samang" system that had been established since they had "chart ships", they still did not eager to complain and told the objection or protest to management or owner of the ship. Moreover, some of them have considered the standard profit sharing system is a fair system. The form of resistance against the disagreement of the profit sharing system applied by "induak samang" is by not going to the sea again with the ship that owns the "chart boat" or moving to another "chart ship" by mentioning the term "perai". Most ship crew members who work on "chart boats" mostly prefer to mute about the results sharing system that sometimes does not match what they expected, or choose to move to another "chart" which he thinks is more prudent in providing revenue sharing by the owner. It has an impact on the difficulties and often changes the crew and captain of their ship.

The low educational background and economic background make the fishermen are challenging to achieve and get financial prosperity, even though they realize that they will not be able to go to sea forever. Their choice after not being able to go to sea is to keep trying in other ways such as returning to the village for farming or opening a small business. The alternative provides us with the fact that the results of the efforts of the sea crews in a few years as fishermen laborers will not provide significant economic improvement.

\section{Conclusion}

The profit sharing system that has been practiced so far is one of the factors causing the inequality to occur, many of the crew complain about this system, but they cannot "violate" or "protest" the system implemented by shipowners. Strength and power remain with the chart owner. The crew of the ship continued to follow the rules set by the owner rather than losing their livelihood as labor fishermen on the "boat chart".

It is necessary to pay attention to a fair profit sharing system for the crew. Why the system of profit sharing is set at its core is for justice for the crew and ship owners. If the payroll system is implemented, the shipowner will find it difficult to apply because of the fish fluctuating when it depends on the weather, season and location. The problem is the value of deductions made by the shipowner before the results are divided into two. Fish sales commission deductions, for example, do not have to be $10 \%$ of sales, for example, can be 5\%, and pieces for ship repairs, should not be issued every month but are dispensed when the ship is damaged or need a repairation. 


\section{References}

[1] Bernstein, Henry \& Others ed. 1992, Poverty and Development in the 1990s, Oxford, OxfordUniversity Pers.

[2] Bedke, Fried Helm 1985, Modernization and Socio Economic Change in the Coasta; Marine Fisheries of Java Some Hypothesies, Bieleveld, University of Bieleveld.

[3] Kusnadi 2002. Konflik Sosial Nelayan: Kemiskinan dan perebutan Sumberdaya Perikanan, L.Kis. Yogyakarta.

[4] Kusnadi 2002. 2007. Jaminan Sosial Nelayan, L.Kis, Yogyakarta.

[5] Layto, Robert 1997. An Introduction to Theory in Anthropology, CambridgeUniversity Press. (Chapter 4: Interactionist Theories)

[6] Mansohen, Johz 1985. Sistem Pemilikan Perahu dan Hubungan Kerja Antara Majikan dan Buruh Nelayan di Citui. Masyarakat Indonesia; Jld 10 No.2.

[7] Marbun, Leonard 2008. Kenaikan BBM dan Kemiskinan Nelayan, P3NM, Medan

[8] Mohan, Giles \& Kristian Stokke 2000. "Participatory Development and Empowermant; the Danger of Localism". Third World Quarterly 21 (2): 247268.

[9] Mubyarto dkk., 1986. Nelayan dan Kemiskinan: Studi Ekonomi Antropologi di Dua Desa Pantai, Rajawali Pers, Jakarta.

[10] Suparlan, Parsudi 1993. Kemiskinan di Perkotaan, Jakarta, Yayasan Obor Indonesia.

[11] Suprapti dkk, 1998.Pola Kehidupan Sosial Budaya Petani dan Nelayan di Daerah

[12] Rawa, Departemen Pendidikan dan Kebudayaan, Jakarta.

[13] Syahrizal dkk, 2008. "Aspek Tindakan dan Perilaku Dalam Kemiskinan: Studi Pada Masyarakat Nelayan Kabupaten Pesisir Selatan Sumatera Barat", Laporan Penelitian Universitas Andalas, Padang.

[14] Tsing, nna L. 2005. Friction: An Etnography of Global Conection, Princeton, PrincetonUniversity Pres.

[15] Yusmar, Yusuf 1994, "Relasi Antar Etnik Baba Tauke dan Pawang Melayu: di Riau”, Prisma; Vol. 23, No.12.'

[16] Zen, Linda Waty, "Analisis Kontribusi Pendapatan Wanita Nelayan di Kelurahan Pasie Nan Tigo, Kecamatan Koto Tangah, Kota Padang, Mangrove dan Pesisir; Vol. IX, No. 1.' 